Article

\title{
An Optimized Methodology for a Hybrid Photo-Voltaic and Energy Storage System Connected to a Low-Voltage Grid
}

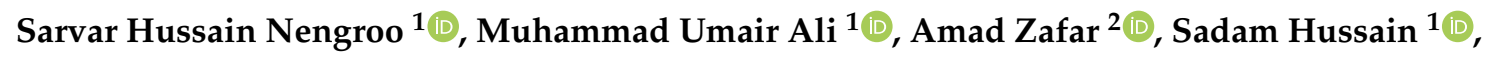 \\ Tahir Murtaza ${ }^{3}{ }^{\mathbb{D}}$, Muhammad Junaid Alvi ${ }^{4}$, K.V.G. Raghavendra ${ }^{1}$ and Hee Jee Kim ${ }^{1, *}$ \\ 1 School of Electrical Engineering, Pusan National University, San 30, Jangjeon 2 Dong, Geumjeong-gu, \\ Busan 46241, Korea; ssarvarhussain@gmail.com (S.H.N.); umairali.m99@gmail.com (M.U.A.); \\ sadamengr15@gmail.com (S.H.); kvg.raghavendra999@gmail.com (K.V.G.R.) \\ 2 Department of Electrical Engineering, Wah Engineering College, University of Wah, Wah Cantt 47040, \\ Pakistan; amad@pusan.ac.kr \\ 3 Department of Physics, Jamia Millia Islamia, New Delhi 110025, India; tahirkas@gmail.com \\ 4 Department of Electrical Engineering, University of Engineering and Technology, Lahore 54890, Pakistan; \\ alvi_junaid@yahoo.com \\ * Correspondence: heeje@pusan.ac.kr; Tel.: +82-51-510-2364
}

Received: 24 December 2018; Accepted: 31 January 2019; Published: 2 February 2019

\begin{abstract}
The growing human population and the increasing energy needs have produced a serious energy crisis, which has stimulated researchers to look for alternative energy sources. The diffusion of small-scale renewable distributed generations (DG) with micro-grids can be a promising solution to meet the environmental obligations. The uncertainty and sporadic nature of renewable energy sources (RES) is the main obstacle to their use as autonomous energy sources. In order to overcome this, a storage system is required. This paper proposes an optimized strategy for a hybrid photovoltaic (PV) and battery storage system (BSS) connected to a low-voltage grid. In this study, a cost function is formulated to minimize the net cost of electricity purchased from the grid. The charging and discharging of the battery are operated optimally to minimize the defined cost function. Half-hourly electricity consumer load data and solar irradiance data collected from the United Kingdom (UK) for a whole year are utilized in the proposed methodology. Five cases are discussed for a comparative cost analysis of the electricity imported and exported. The proposed scheme provides a techno-economic analysis of the combination of a BSS with a low-voltage grid, benefitting from the feed-in tariff (FIT) scheme.
\end{abstract}

Keywords: batter storage system; electricity consumer load; solar irradiance; solar photovoltaic system

\section{Introduction}

The increase in global warming is due to climate change beyond doubt. One of the main causes of the production of greenhouse gasses is the fossil fuel-based energy source. The Intergovernmental Panel on Climate Change (IPCC) has calculated an increase in the concentration of carbon dioxide $\left(\mathrm{CO}_{2}\right)$, methane, and nitrous oxide by $40 \%, 150 \%$, and $20 \%$, respectively, since preindustrial times [1]. Till 2015, the combustion of fossil fuels produced two-thirds of the global $\mathrm{CO}_{2}$ approximately [2]. A large number of harmful gasses are produced from the combustion of fossil fuels from industrial zones, and their adverse effects on health and environment have been discussed in $[3,4]$. The increasing concentration rate of 2-3 ppm/year is expected to reach the range of 535-983 ppm/year at the end of the 21st century [5]. This motivates to shift from the hazardous and non-replenishing energy source towards ever-green energy sources, especially for electrical power generation, which produces about $42 \%$ of the global $\mathrm{CO}_{2}$ emission [6]. The electricity generated from renewable energy 
sources can be foreseen to take the place of petroleum in vehicles, which is the main source of environmental pollutants.

With the advancements of science and technology, a large number of alternatives for producing energy on a sustainable level are available [7]. Since the late 1990s, the main driving force to boosting alternative energy sources has been global warming linked to $\mathrm{CO}_{2}$ emission. In the last two decades, there has been considerable advancement in the field of photovoltaic (PV) technology. The price of PV modules has shown a decrease of $7.5 \%$, and the overall production of PV modules throughout the globe has ramped up by $18 \%$ per year. The report in reference [8] shows that the compound annual growth rate (ACGR) of PV installation was 24\% between 2010 and 2017, with China and Taiwan taking the lead with a share of $70 \%$, and Asia-Pacific and Central Asia having a share of $14.8 \%$ in the production of PV modules in 2017. The present order of magnitude for electricity production from solar PV technology is higher than those for the production of electricity from hydraulic and nuclear plants and fossil fuels [9]. Reports from the International Energy Agency and Renewable Energy Policy Network show that the total installed capacity of solar PV systems in 2009 was 23 GW, which increased by five times, to $137 \mathrm{GW}$, in 2013 and to $177 \mathrm{GW}$ in 2014. In 2016, the major contributions to the world's built-in solar PV capacity of $303 \mathrm{GW}$ came from the European Union with $106 \mathrm{GW}$ (Germany $41.3 \mathrm{GW}$ ), followed by China with 77.4 GW, Japan with $42.8 \mathrm{GW}$, and the USA with 40.9 GW $[3,6,10,11]$. The global trend in the growth of the installed PV capacity can be seen in Figure 1 [11].

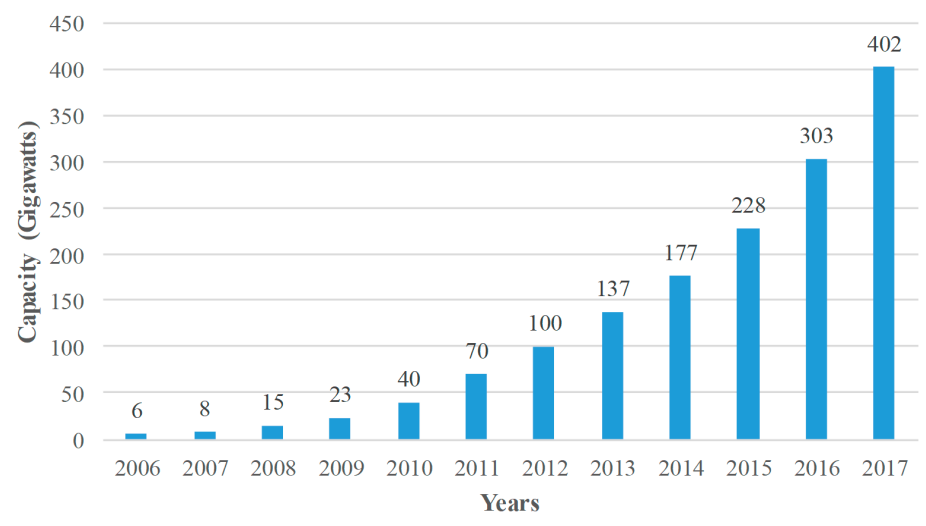

Figure 1. Installed global solar photovoltaic (PV) capacity (2006 to 2017) [11].

A solar PV cell consists of a semiconductor diode, which generates the electron-hole pairs when photons of energy greater than the bandgap energy of the semiconductor material are incident on it. The various types of materials used in PV technology are monocrystalline, polycrystalline, thin films [12-14]. Amorphous silicon technology is the eco-friendliest technology and has a low cost, which can be as low as 0.06-0.09€/WP.

To tackle climate change and ensure energy security, the government of UK set up financial incentives to motivate the consumers deploying Renewable Energy Sources (RES) [15]. Various plans and projects have been initiated worldwide to merge Renewable Energy (RE) technologies for energy production, keeping the stability of electricity production and national economies in view [16]. The significance of small-scale renewable energy is underlined in UK's microgeneration strategy to provide financial support incentives to set up these goals [17]. In many European Countries (EC) like the UK, microgeneration technologies are encouraged by various government policies and schemes, viz., feed-in tariff (FIT), Renewable Obligation (RO), reduced value-added tax (VAT), and capital grants for households. FIT is the mostly adopted scheme for promoting RE deployment and is responsible for the greatest share of RE development surpassing both Renewable Portfolio Standards (PS) and tax incentives [11]. In EU, FIT policies have led to the installation of more than $15000 \mathrm{MW}$ of solar PV power and more than 55000 MW of wind power from 2000 to 2009 [18]. The pathways analysis shows that small-scale solutions like heat pumps will help the UK government to meet the $80 \%$ reduction in domestic greenhouse emission gasses by 2050 and reach the target of 15\% renewable energy by 
2020 [17]. Within the FIT scheme, the large energy providers connect with the small-scale RE producers to purchase their generated electricity for a fixed tariff.

Due to the irregular nature of the solar PV systems, the installation of large-scale distributed PV systems raises technical issues with the grid [19]. The various problems that arise due to the penetration of a distributed PV system include reverse-power flow, steady-state voltage rise, losses, protection, power-quality issues, etc. [20,21]. The increasing electricity consumption and the decrease in the cost of PV modules and battery packs have advanced the self-consumption of electricity [22,23]. According to reference [24], the various types of batteries used in hybrid PV systems are deep-cycle batteries (lead-acid, flooded-type, valve-regulated-type sodium-sulphur, lithium-ion, and metal-air flow batteries). Battery energy storage (BSS) systems re receiving great attention for providing support to the grid in various applications, particularly in lithium-ion batteries [25-27]. The total global battery storage capacity in 2017 was $4.67 \mathrm{TWh}$, which is expected to increase to 11.89-17.72 TWh by 2030 [28]. Chee et al. [19] used the method of Lagrange multiplier to maximize the revenue over a fixed period of time, while maintaining the battery storage constant. In reference [29], a linear programming (LP) algorithm was used with a combined PV and BSS for the optimal scheduling of power. Dynamic programming (DP) was used for the optimal power flow management for the grid-connected PV system, as described in reference [30]. The performance and the cost-effectiveness were analyzed for the induction of batteries with the PV system in several studies [31-33]. Ratnam et al. [34] used a quadratic program (QP) method to schedule a grid-tied hybrid PV and BSS. This methodology was basically designed for electricity supplier companies to reduce the peak hour cost to the customers. They validated their proposed methodology using measured data of 145 customers in Australia. Their results suggested that most of the customers got benefits by adopting this technique. In another study [35], a strategy was proposed to the customers for the optimum use of their hybrid PV and BSS. The proposed methodology charged the BSS depending upon its state of charge (SOC), and the extra PV energy was supplied to the grid when the BSS showed full SOC level. When the PV output energy was less than the load demand, the BSS was discharged, which results in a low electricity bill. Hassan et al. [36] reduced the electricity price by discharging the saved energy of BSS in the peak hours. Similarly, some studies presented optimum strategies to reduce the electricity prices of the grid-tied hybrid PV and BSS [37-39]. A study of the hybrid dual battery storage system discussed the cost analysis, omitting the high capital cost of the two batteries [40]. Recently, Singh et al. [41] improved the iterative method of electric system cascade analysis for an isolated hybrid PV and BSS. Their proposed methodology significantly improved the system efficiency.

In this study, an optimum strategy to decrease the operating electricity cost of a hybrid PV and BSS connected with a low-voltage grid is presented. The generated solar energy is utilized onsite for the consumer load demand. When the solar energy generation is higher than the load demand, the extra energy can be either stored in the battery or sold to the grid. Firstly, the extra PV energy charges the battery, then it is exported to the grid. If the production of solar energy is lower than the demand, the power can be imported to meet the unmet load demand. The stored battery energy is discharged only during peak hours to reduce the peak load energy cost, and if the battery is at a lower specific SOC level before peak hours than after being charged using the grid power, which results in the reduction of the overall price of electricity for a whole day. The installed capacity of the solar PV system used in this study is $3 \mathrm{~kW}$; the effect of varying the battery capacity is discussed in Section 4 of this paper.

\section{Materials and Methods}

\subsection{PV Data and Consumer Load Data}

The current world is facing a dearth of energy, and this scarcity has stimulated researchers to manipulate different renewable energy sources. The abundant, eco-friendly, and replenishable features of renewable energy sources make them suitable to generate electricity in favorable climatic conditions. The limitations of exclusively autonomous RES can be overcome by hybrid PV or wind systems in 
terms of efficiency, stability, and reliability, while operating at a minimum cost [42-44]. Solar energy is considered the cheapest and eco-friendliest source to mitigate the energy crisis. However, solar generation has its own constraints and limitations and depends upon weather conditions, day-time hours, and other factors. There exist several days in a year when a solar PV system generates much more power than the consumer demand, and there exist some days in which power generation is lower than the consumer demand, as shown in Figure 2. This issue makes it impossible to provide the requested energy at each instant. So, a hybrid PV and BSS connected with a grid was studied.
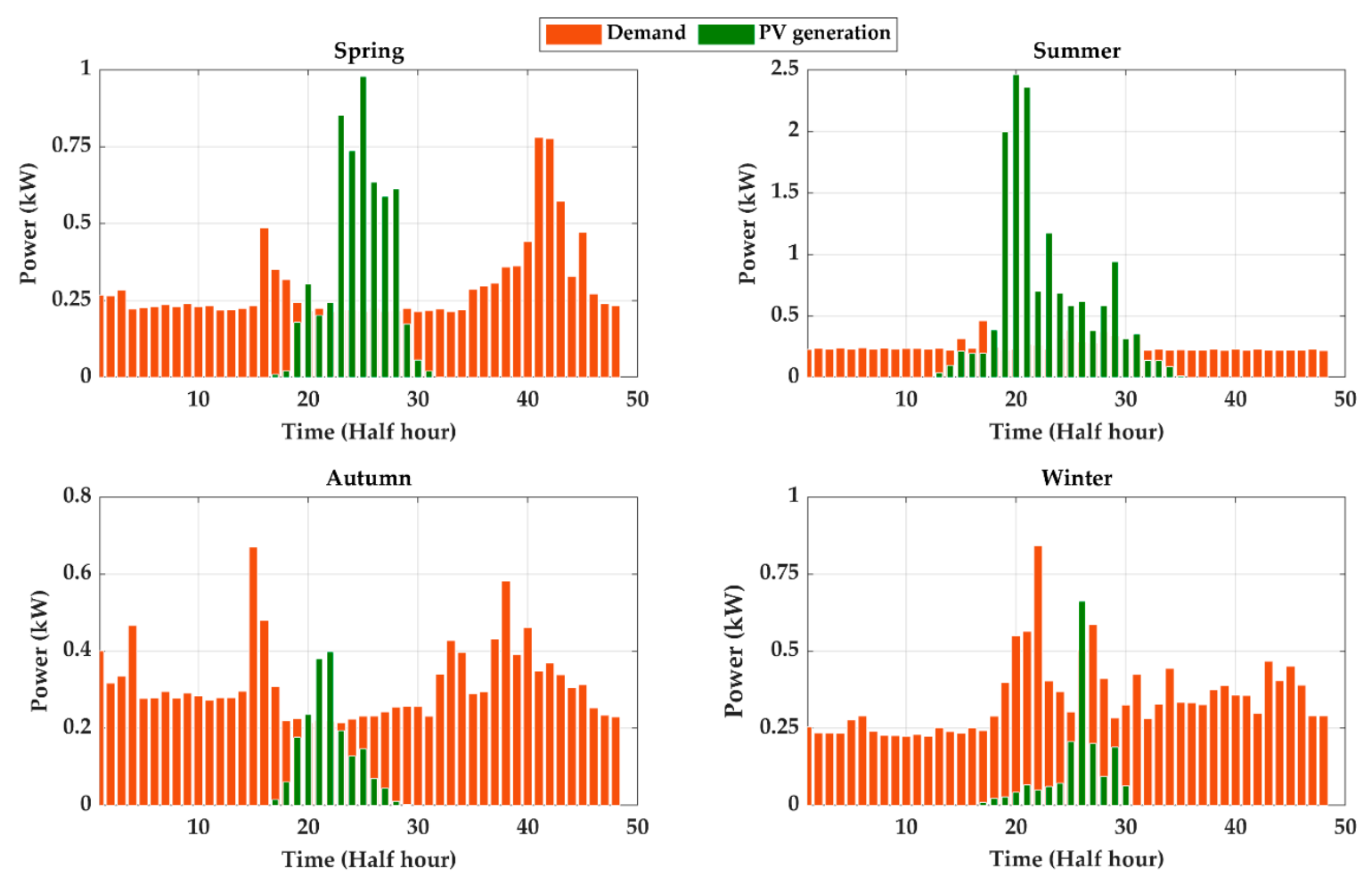

Figure 2. Solar PV generation and consumer load demand in the four seasons.

In Figure 2, the green bars show solar PV generation, and the purple bars show the consumer load demand. The plots refer to the four seasons during a year. The graphs on the top left and right indicate spring and summer, and the lower left and the right graphs indicate autumn and winter. This indicates that solar energy can be used onsite to meet the load demand, can stored in batteries for future use, and can be sold to the grid, benefitting from the FIT scheme. Therefore, an optimal scheme is required to utilize onsite solar energy and store the excess power to maximize the daily savings of the customers.

Consumer load demand data were collected on a half-hour basis from ELEXON [45] for a whole year, and solar PV generation data were collected from the Sheffield microgeneration database [46] for a whole year. The Sheffield microgeneration database stores and collects solar PV generation from voluntary owners in the United Kingdom (UK).

\subsection{Economy 7 Tariff}

This tariff is categorized as off-peak and on-peak. The off-peak tariff offers a low rate of electricity, while the on-peak tariff corresponds to a higher rate. About $9 \%$ of the customers in the UK are subscribed to the Economy 7 tariff [47]. As shown in Figure 3, the off-peak period is $7 \mathrm{~h}$, and the remaining hours are on-peak hours. The rate of electricity during the off-peak hours is $6 \mathrm{p} / \mathrm{kWh}$, and that for the on-peak hours is $15.8 \mathrm{p} / \mathrm{kWh}$. 


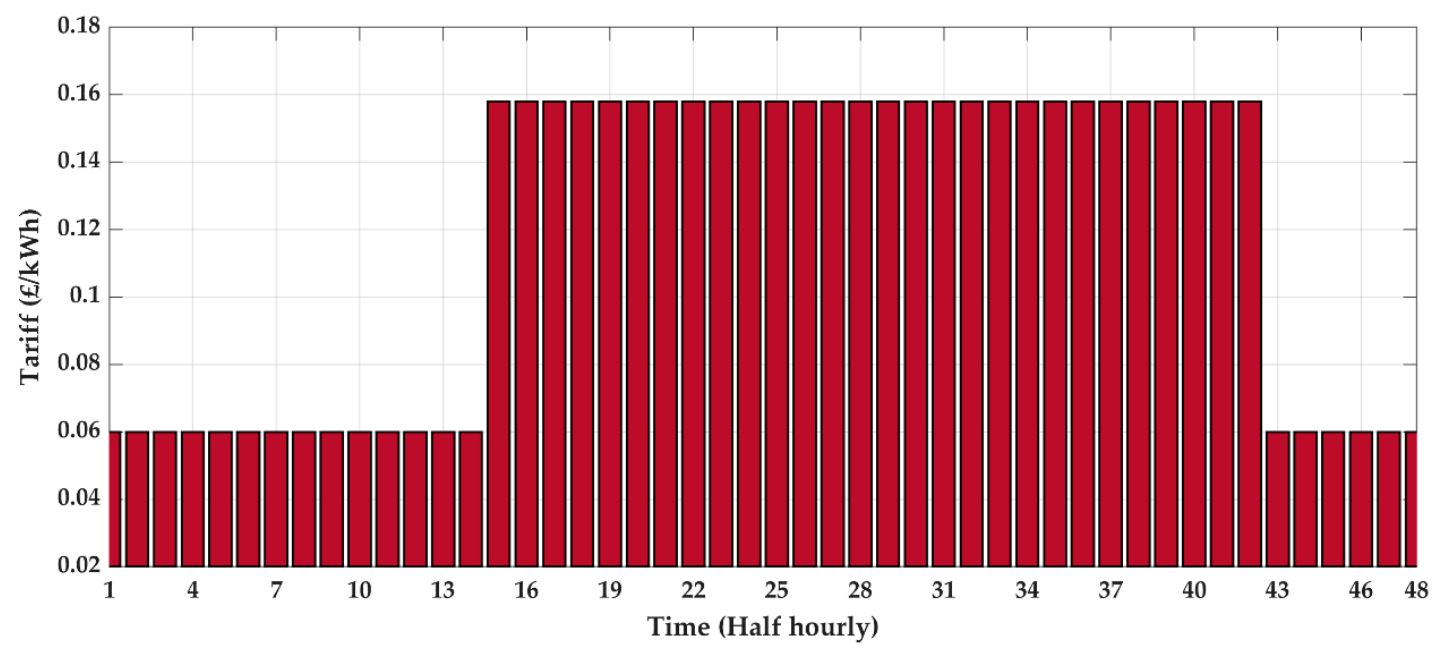

Figure 3. Economy 7 tariff.

\section{Proposed Methodology}

The block diagram for our proposed hybrid PV and BSS indicating the energy flow directions is shown in Figure 4. It includes solar PV modules, an AC to DC converter, a DC to AC inverter, a customer load demand, and a controller.

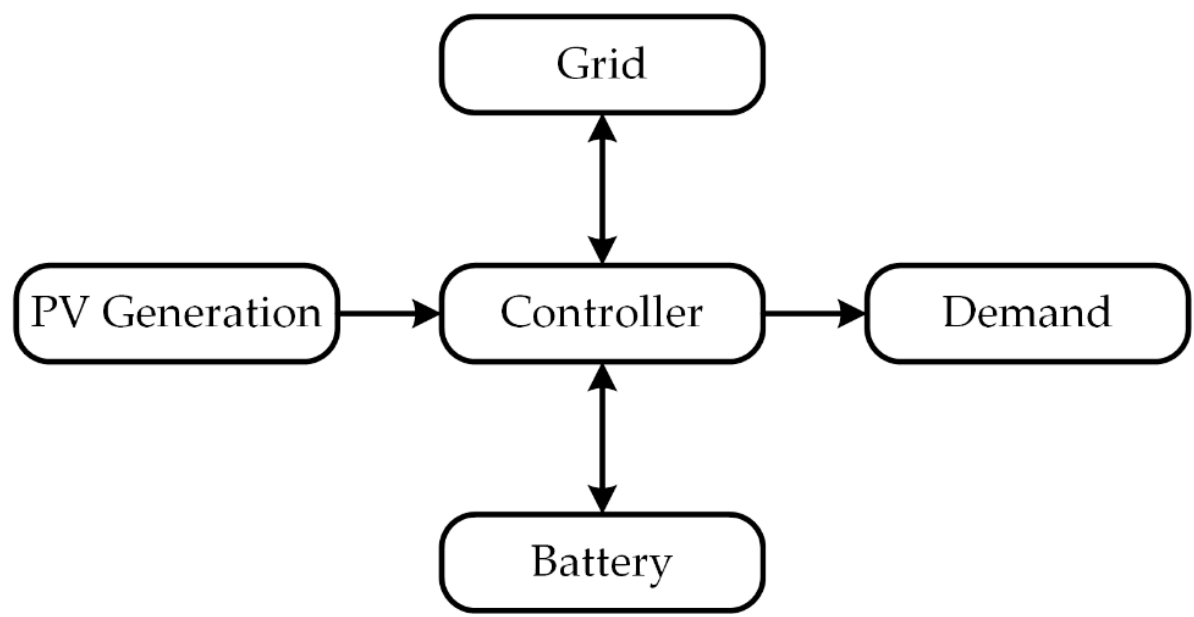

Figure 4. Block diagram of the proposed hybrid PV-BSS.

The solar PV system is operated to meet the onsite load demand. As shown in Figure 2, sometimes the PV generation exceeds the load demand, and the excess power is stored in the battery. In the proposed optimal strategy, as the battery is fully charged, the excess power is directed to the grid. On the contrary, when the PV generation is insufficient to meet the demand, the power can be imported from the grid or the BSS, depending upon the time of use. The controller first checks the time of use; if the time lies between the peak hours, the controller checks the battery's SOC level. The load is shifted to the battery if the SOC level of the battery is more than $5 \%$. Otherwise, the unmet demand will be provided by the grid. Besides, the controller regularly checks if the SOC level of the battery is lower than $50 \%$. The battery should be charged two hours before the first peak hour using the grid. This results in reducing the overall daily cost of electricity. The battery should be charged two hours before the peak hours' start because it takes approximately two hours to charge the battery. This time can be adjusted depending upon the charging time of the battery. The aforementioned strategy to provide power to the load from the hybrid PV-BSS connected with a low voltage-grid is shown in Figure 5. 


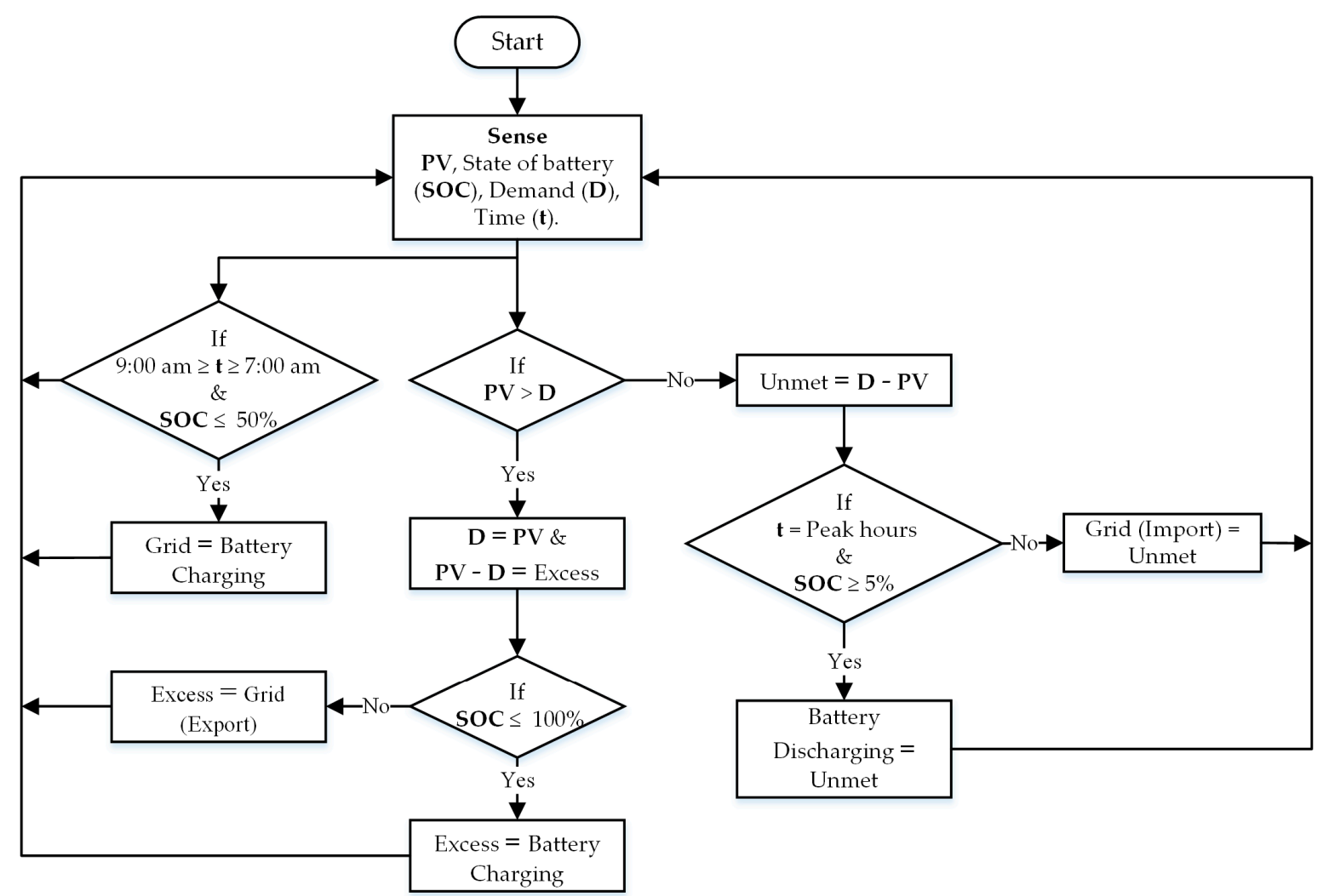

Figure 5. Flowchart of the hybrid PV and battery storage system (BSS) system. SOC, state of charge.

Such a control logic and management are evaluated for a whole year. The mathematical function used to determine the cost is given by Equation (1):

$$
f=\min \left[f_{P V}+f_{B S S}+\sum_{d, t}\left[\left(P_{\text {load }}-P_{p v}\right) p_{\text {tariff }}\right] \times \Delta t\right]
$$

subjected to:

$$
p_{\text {tariff }}=\left\{\begin{array}{l}
p_{i_{\text {tar }}} \text { if } P_{\text {load }}>P_{p v} \\
p_{e_{\text {tar }}} \text { if } P_{p v}>P_{\text {load }}
\end{array}\right.
$$

where $f_{P V}$ and $f_{B S S}$ are the capital cost of the PV system storage system, $d$ is the day, $t$ is the time, $P_{p v}$ is the power generated by the PV system, $P_{\text {load }}$ is the demand of the consumer, $P_{i_{-} \text {tar }}$ is the import tariff at which the power is imported to meet the unmet demand, $P_{\mathcal{e}_{-} t a r}$ is the export tariff at which the excess power is exported to the grid.

\section{Results and Discussion}

Energy plays a major role in the socio-economic progress of any country. Taking into consideration the depletion of fossil fuels, concerns about climate change, increasing energy demand, and the increasing population, the generation of electrical power is entering a new phase. Real-time data of solar irradiance and consumer load demand are utilized in this study. The data were collected for a whole year on a half-hour basis from the UK $[46,48]$. Figure 3 represents the pictorial view of the proposed study. The controller is the main unit, which decides the direction of power flow. As shown in Figure 2, there are some days, like in summer, where solar irradiance is high and generates much more power than required to meet the demand. The excess power is directed by the controller to charge the battery. As the battery indicates full SOC, the power is sold to the grid at the export rate. However, as shown in Figure 2, there are some days, as in winter, when the solar irradiance is low, 
and the solar energy is not enough to meet the demand. The controller imports power at the prescribed rate to meet the unmet demand, but during the peak hours, the battery is utilized to feed the consumer demand. The controller optimally charges and discharges the battery to minimize the objective cost function of purchasing the power from the grid. The effect of varying the battery capacity is evaluated to minimize the cost function. However, varying the battery capacity applies to only three cases in which the BSS is present. The demonstration of all the five cases is reported below.

\subsection{Case 1 (Only Grid)}

No solar PV or storage system are installed in this case. The grid provides electricity to meet the consumer demand solely with the economy 7 tariff applied. For the whole year, the rate of electricity during peak hours is $0.158 £ / \mathrm{kWh}$ and, during off-peak hours, is $0.06 £ / \mathrm{kWh}$. The amount of power purchased for the whole year is shown in Figure 6, and the total cost is shown in Table 1.

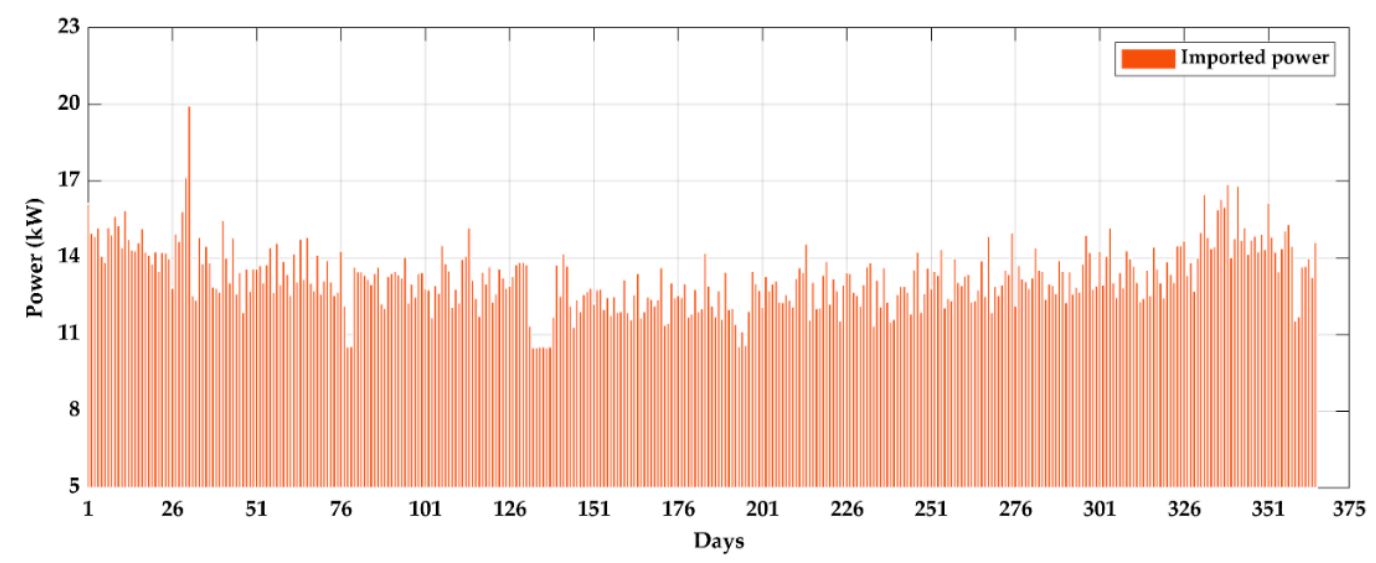

Figure 6. Power purchased from the grid.

\subsection{Case 2 (Grid and Solar PV System)}

In this case, the solar PV system is installed, and the consumer demand is met by the solar PV system alone or by both PV system and grid. On a priority basis, the demand is met by the solar PV system first. If the energy provided by the PV system is insufficient, energy is imported from the grid to meet the unmet demand at the prescribed rate during the on-peak and off-peak hours. The same applies when the solar energy is more than the energy required, and the excess power is sold to the grid at the prescribed export rate of $0.04 £ / \mathrm{kWh}$. The imported and exported power, in this case, is shown in Figure 7, and the cost is shown in Table 1.

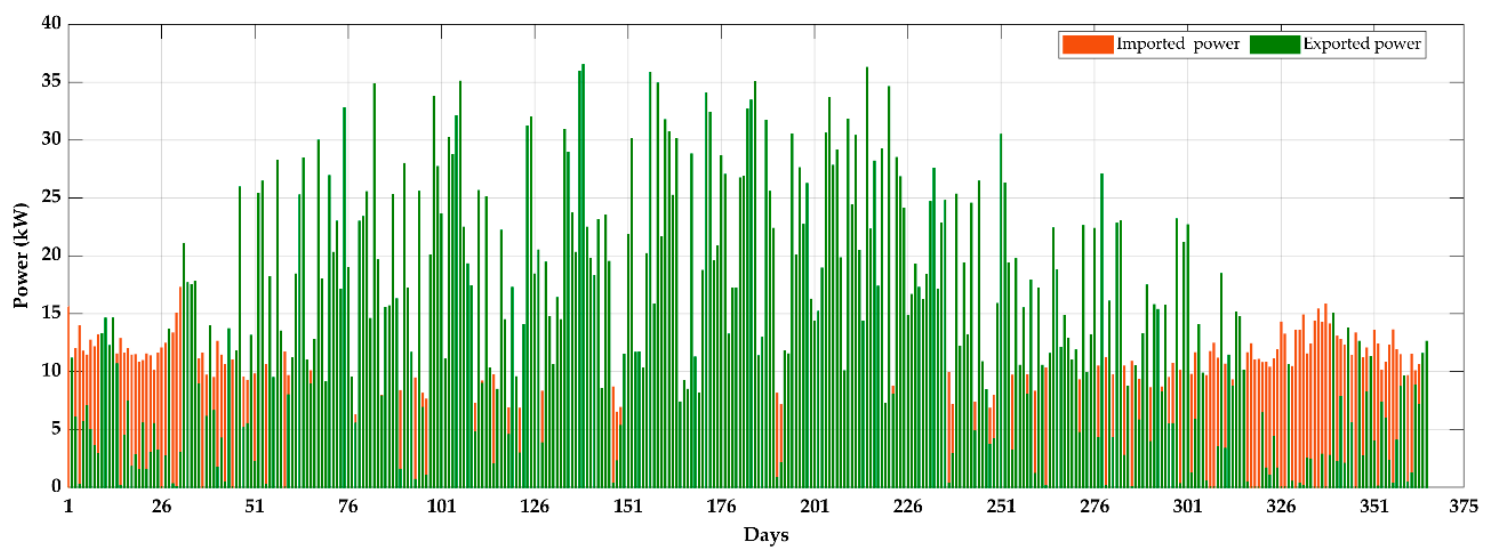

Figure 7. Imported and exported power profiles with a solar PV system and grid. 


\subsection{Case 3 (Grid, Solar PV System, and BSS)}

In this case, a solar PV-BSS connected to a low-voltage grid is evaluated. The solar PV system feeds the demand. If there is surplus power, the same is stored in the battery or exported to the grid at the export rate of $0.04 £ / \mathrm{kWh}$. However, if there is unmet demand, power is provided by the battery irrespective of the on- and off-peak hours. When the SOC of the battery reaches the minimum threshold limit, the power is purchased from the grid at the respective rate. The imported and exported powers, in this case, are shown in Figure 8, and the cost analysis of imported and exported power by varying the battery capacity is shown in Table 1 .

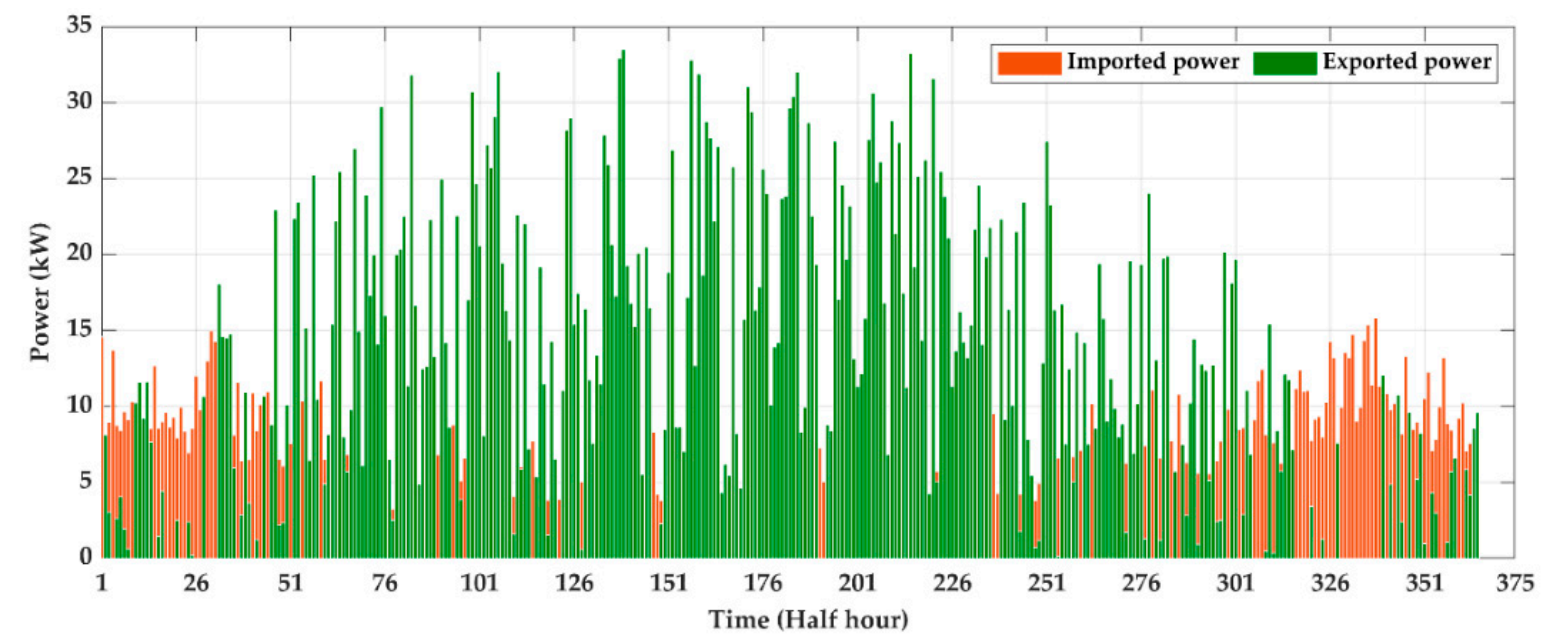

Figure 8. Imported and exported power with a PV system, grid, and BSS.

\subsection{Case 4 (Grid, PV, and Utilization of BSS during the Peak Hours Only)}

This case is similar to the previous case 3, with a solar PV system, grid, and BSS. The solar PV system fulfills the consumer demand initially. The extra power is directed to the battery or sent to the grid, and the required unfulfilled power is taken from the grid. However, during the peak hours, the battery is utilized to provide the unfulfilled power. The power needed or sold to the grid is shown in Figure 9. By changing the battery capacity, the costs of the imported and the exported power are shown in Table 1.

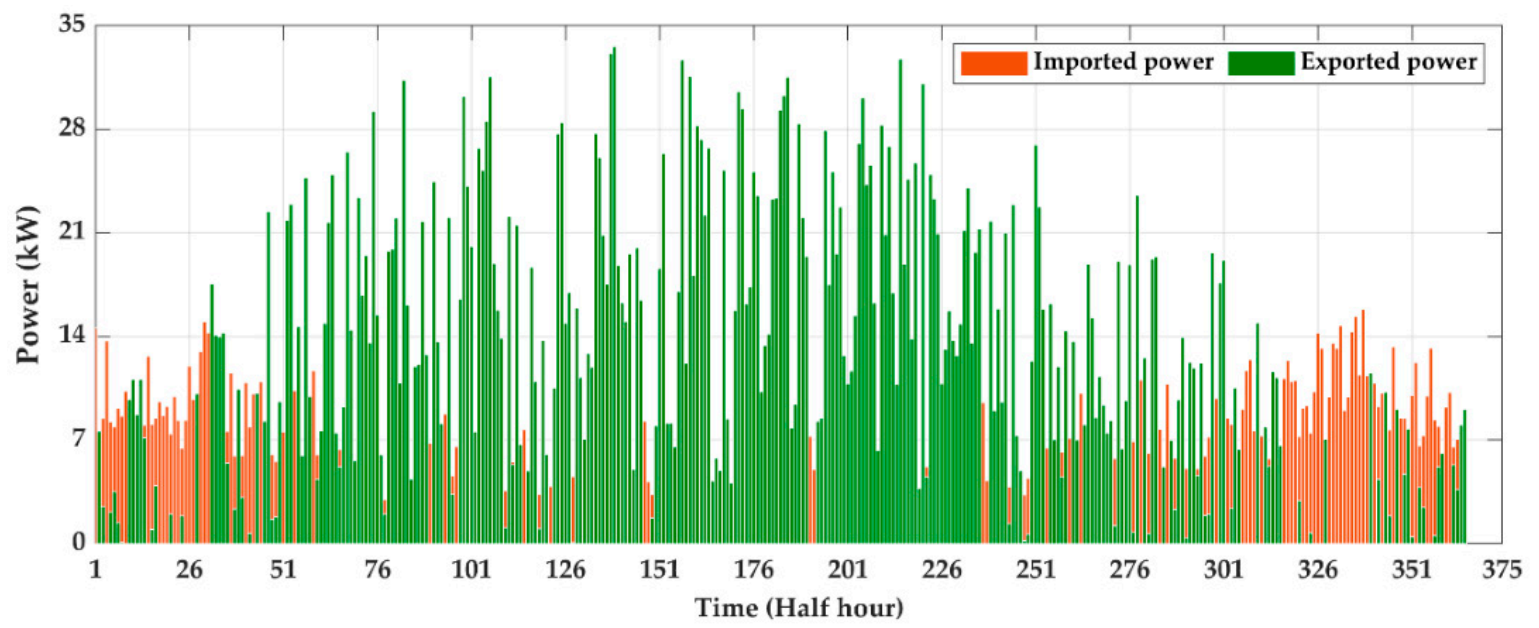

Figure 9. Imported and exported power with a PV system, grid, and BSS utilized during peak hours. 


\subsection{Case 5 (Proposed Strategy)}

The strategy of meeting the consumers' demand is the same as in case 4. However, in this case, the controller keeps on checking the PV generation, load, and SOC of the battery. The battery is charged from the grid two hours before the peak hours' start if the SOC of the battery is less than $50 \%$. The power purchased or exported to the grid is shown in Figure 10. The effect of varying the battery capacity is shown in Table 1, in terms of the cost of the imported and exported power.

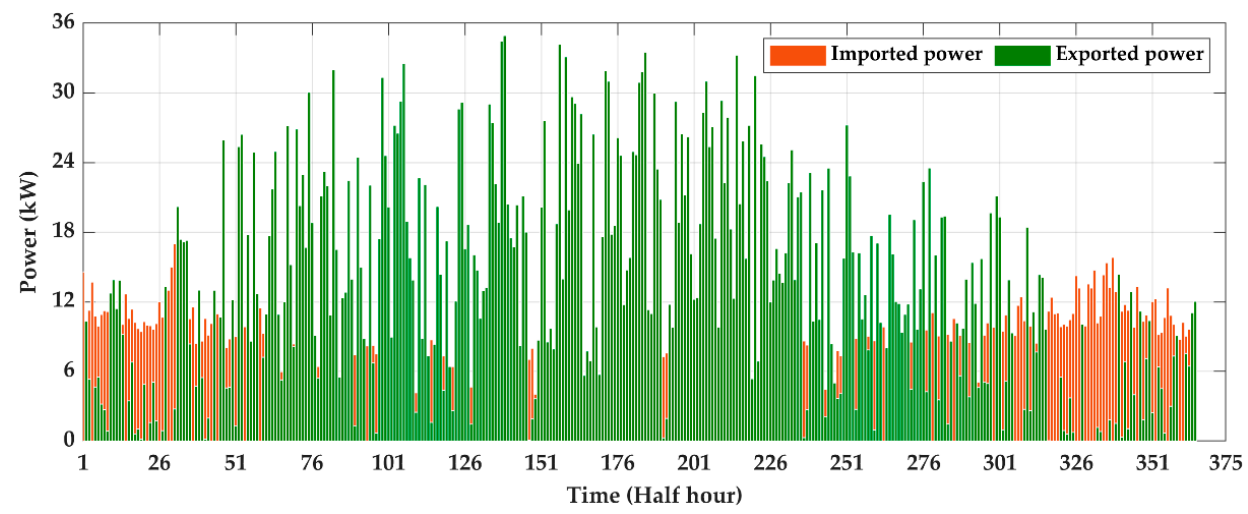

Figure 10. Imported and exported power with a PV system, grid, and BSS operated during on- and off-peak hours.

Table 1. Cost analysis of the cases 1, 2, 3, 4, and 5 .

\begin{tabular}{ccccc}
\hline Case & $\begin{array}{c}\text { Battery Capacity } \\
\mathbf{( k W h )}\end{array}$ & $\begin{array}{c}\text { Cost of Importing } \\
\text { Electricity }(\boldsymbol{E}) \mathbf{( A )}\end{array}$ & $\begin{array}{c}\text { Cost of Exporting } \\
\text { Electricity }(\mathfrak{E}) \mathbf{( B )}\end{array}$ & $\begin{array}{c}\text { Net Value (£) } \\
(\mathbf{C}=\mathbf{A}-\mathbf{B})\end{array}$ \\
\hline 1 & 0 & 288.344 & 0 & 288.344 \\
2 & 0 & 162.005 & 118.9234 & 43.099 \\
3 & 2 & 110.8290 & 103.5720 & 7.2570 \\
& 3 & 92.2453 & 96.5552 & -4.3129 \\
4 & 2 & 100.7748 & 100.00374 & 0.7373 \\
& 3 & 85.6395 & 93.6068 & -7.9673 \\
5 & 2 & 101.3259 & 108.2678 & -6.9419 \\
& 3 & 89.7309 & 106.9980 & -17.2671 \\
\hline
\end{tabular}

Table 1 gives the comparative cost analysis of the cases discussed above. The net cost of imported and exported electricity in case 1 is $288.344 €$, and the net value of the imported and exported electricity in case 2 is $43.099 \mathrm{E}$. In case 3, the net cost of power purchased for the $2 \mathrm{kWh}$ battery is $7.2570 £$, which reduced to $-4.3129 £$ when a $3 \mathrm{kWh}$ battery was used. In case 4 , the price of the imported power on the $2 \mathrm{kWh}$ battery is $0.7373 £$, which decreased to $-7.9673 £$. In case 5 , the value of the power purchased on the $2 \mathrm{kWh}$ battery is $-6.9419 £$, which decreased to $-17.2671 £$. The negative sign indicates the net savings. From the cost analysis, it can be concluded that the selection of the battery capacity plays a crucial role for the optimal energy management. The optimum value of battery capacity must be selected while considering its cost.

\section{Conclusions}

There is an urgent need to make the transition from hydrocarbons towards the exploitation of natural resources like solar and wind energy. This paper proposes an optimized hybrid solar PV and BSS connected to a low-voltage grid and enrolled into the FIT scheme. A cost function was formulated to determine the cost of the electricity imported and exported for the whole system. The BSS charges using the extra energy generated by the PV system before it is exported to the grid. In addition, the proposed strategy also charges the BSS from the grid before peak hours if the SOC level of the BSS is lower than the threshold value. The proposed strategy discharges the BSS energy only during 
peak hours to reduce the overall daily electricity cost. Real-time data of solar irradiance and load collected from the customers were used to validate the proposed methodology. The proposed scheme showed the effect of optimally charging and discharging the battery and varying the battery capacity on its actual function. This proposed optimized methodology with the economy 7 tariff indicates an important possibility of energy management of residential loads benefitting from the FIT incentives and can be applied to any type of the tariff scheme. The proposed strategy results in net savings and attracts customers to systems allowing the self-utilization of solar energy.

Author Contributions: Conceptualization, S.H.N., M.U.A., A.Z., and H.J.K.; Data curation, S.H.N. and S.H.; Investigation, M.U.A., A.Z., and M.J.A.; Methodology, S.H.N., M.U.A., and T.M.; Software, S.H.N., A.Z., and M.J.A.; Supervision, H.J.K.; Writing-original draft, S.H.N., S.H., and K.V.G.R.; Writing一review \& editing, S.H.N. and M.U.A.

Funding: This research was supported by the Basic Research Laboratory through the National Research Foundations of Korea funded by the Ministry of Science, ICT and Future Planning (NRF-2015R1A4A1041584). This research was also supported by Brain Korea 21 Center for Creative Human Resource Development Program for IT Convergence of Pusan National University.

Conflicts of Interest: The authors declare no conflict of interest.

\section{References}

1. The Core Writing Team; Pachauri, R.K.; Meyer, L. The Intergovernmental Panel on Climate Change, Climate Change 2014-Synthesis Report; IPCC: Geneva, Switzerland, 2014.

2. Available online: https://ec.europa.eu/jrc/en/news/global-co2-emissions-fossil-fuels-and-industrialprocesses-stall (accessed on 2 November 2018).

3. Houghton, D. Global Warming: The Complete Briefing; Cambridge University Press: Cambridge, UK, 1997.

4. Peet, J. Energy and the Ecological Economics of Sustainability; Island Press: Washington, DC, USA, 1992.

5. Andres, R.J.; Gregg, J.S.; Losey, L.; Marland, G.; Boden, T.A.J.T.B.C.; Meteorology, P. Monthly, global emissions of carbon dioxide from fossil fuel consumption. Tellus B Chem. Phys. Meteorol. 2011, 63, 309-327. [CrossRef]

6. Alexander, L.V.; Allen, S.K.; Bindoff, N.L.; Breon, F.-M.; Church, J.A.; Cubasch, U.; Emori, S.; Forster, P.; Friedlingstein, P.; Gillett, N. Summary for Policymakers; Cambridge University Press: Cambridge, UK, 2013.

7. Turner, J.A. A realizable renewable energy future. Science 1999, 285, 687-689. [CrossRef] [PubMed]

8. Fraunhofer ISE. Photovoltaics Report; Fraunhofer ISE: Freiburg, Germany, 2014.

9. Shah, A.; Torres, P.; Tscharner, R.; Wyrsch, N.; Keppner, H. Photovoltaic technology: The case for thin-film solar cells. Science 1999, 285, 692-698. [CrossRef] [PubMed]

10. Mobil, E. The Outlook for Energy: A View to 2040; Exxon Mobil: Irving, TX, USA, 2013.

11. REN21. Renewable Energy Policy Network for the 21st Century Renewables 2017 Global Status Report; REN21 Secretariat: Paris, France, 2017; pp. 1-302.

12. Stoppato, A.J.E. Life cycle assessment of photovoltaic electricity generation. Energy 2008, 33, $224-232$. [CrossRef]

13. Aulich, H.A.; Schulze, F.W. Crystalline silicon feedstock for solar cells. Prog. Photovolt. Res. Appl. 2002, 10, 141-147. [CrossRef]

14. Phylipsen, G.J.M.; Alsema, E.A. Environmental Life-Cycle Assessment of Multicrystalline Silicon Solar Cell Modules; Department of Science, Technology and Society, Utrecht University Utrecht: Utrecht, The Netherlands, 1995.

15. Cherrington, R.; Goodship, V.; Longfield, A.; Kirwan, K. The feed-in tariff in the UK: A case study focus on domestic photovoltaic systems. Renew. Energy 2013, 50, 421-426. [CrossRef]

16. Pyrgou, A.; Kylili, A.; Fokaides, P.A. The future of the Feed-in Tariff (FiT) scheme in Europe: The case of photovoltaics. Energy Policy 2016, 95, 94-102. [CrossRef]

17. Department of Energy and Climate Change (DECC). Microgeneration Strategy; Technical Report; DECC: London, UK, 2011.

18. European Photovoltaic Industry Association (EPIA). Global Market Outlook for Photovoltaics until 2014; EPIA: Brussels, Belgium, 2012.

19. Nge, C.L.; Ranaweera, I.U.; Midtgård, O.M.; Norum, L. A real-time energy management system for smart grid integrated photovoltaic generation with battery storage. Renew. Energy 2019, 130, 774-785. [CrossRef] 
20. Masters, C.L. Voltage rise: The big issue when connecting embedded generation to long $11 \mathrm{kV}$ overhead lines. Power Eng. J. 2002, 16, 5-12. [CrossRef]

21. Ueda, Y.; Kurokawa, K.; Tanabe, T.; Kitamura, K.; Sugihara, H. Analysis results of output power loss due to the grid voltage rise in grid-connected photovoltaic power generation systems. IEEE Trans. Ind. Electron. 2008, 55, 2744-2751. [CrossRef]

22. Alet, P.J.; Baccaro, F.; De Felice, M.; Efthymiou, V.; Mayr, C.; Graditi, G.; Juel, M.; Moser, D.; Petitta, M.; Tselepis, S.; et al. Quantification, challenges and outlook of PV integration in the power system: A review by the European PV technology platform. In Proceedings of the EU PVSEC, Hamborg, Germany, 14-18 September 2015.

23. Karakaya, E.; Hidalgo, A.; Nuur, C.J.R.; Reviews, S.E. Motivators for adoption of photovoltaic systems at grid parity: A case study from Southern Germany. Renew. Sustain. Energy Rev. 2015, 43, 1090-1098. [CrossRef]

24. Zsiborács, H.; Baranyai, N.H.; Vincze, A.; Háber, I.; Pintér, G.J.E. Economic and Technical Aspects of Flexible Storage Photovoltaic Systems in Europe. Energies 2018, 11, 1445. [CrossRef]

25. Hesse, H.; Schimpe, M.; Kucevic, D.; Jossen, A.J.E. Lithium-ion battery storage for the grid-A review of stationary battery storage system design tailored for applications in modern power grids. Energies 2017, 10, 2107. [CrossRef]

26. Umair Ali, M.; Hussain Nengroo, S.; Adil Khan, M.; Zeb, K.; Ahmad Kamran, M.; Kim, H.J. A real-time simulink interfaced fast-charging methodology of lithium-ion batteries under temperature feedback with fuzzy logic control. Energies 2018, 11, 1122. [CrossRef]

27. Ali, M.; Kamran, M.; Kumar, P.; Nengroo, S.; Khan, M.; Hussain, A.; Kim, H.J. An Online Data-Driven Model Identification and Adaptive State of Charge Estimation Approach for Lithium-ion-Batteries Using the Lagrange Multiplier Method. Energies 2018, 11, 2940. [CrossRef]

28. Ralon, P.; Taylor, M.; Ilas, A.; Diaz-Bone, H.; Kairies, K. Electricity Storage and Renewables: Costs and Markets to 2030; IRENA: Abu Dhabi, United Arab Emirates, 2017.

29. Nottrott, A.; Kleissl, J.; Washom, B. Energy dispatch schedule optimization and cost benefit analysis for grid-connected, photovoltaic-battery storage systems. Renew. Energy 2013, 55, 230-240. [CrossRef]

30. Balcombe, P.; Rigby, D.; Azapagic, A. Energy self-sufficiency, grid demand variability and consumer costs: Integrating solar PV, Stirling engine CHP and battery storage. Appl. Energy 2015, 155, 393-408. [CrossRef]

31. Stenzel, P.; Linssen, J.; Fleer, J. Impact of different load profiles on cost optimal system designs for battery supported PV systems. Energy Procedia 2015, 75, 1862-1868. [CrossRef]

32. Gährs, S.; Mehler, K.; Bost, M.; Hirschl, B. Acceptance of Ancillary Services and Willingness to Invest in PV-storage-systems. Energy Procedia 2015, 73, 29-36. [CrossRef]

33. Bortolini, M.; Gamberi, M.; Graziani, A. Technical and economic design of photovoltaic and battery energy storage system. Energy Convers. Manag. 2014, 86, 81-92. [CrossRef]

34. Ratnam, E.L.; Weller, S.R.; Kellett, C.M. An optimization-based approach to scheduling residential battery storage with solar PV: Assessing customer benefit. Renew. Energy 2015, 75, 123-134. [CrossRef]

35. Linssen, J.; Stenzel, P.; Fleer, J. Techno-economic analysis of photovoltaic battery systems and the influence of different consumer load profiles. Appl. Energy 2017, 185, 2019-2025. [CrossRef]

36. Hassan, A.S.; Cipcigan, L.; Jenkins, N. Optimal battery storage operation for PV systems with tariff incentives. Appl. Energy 2017, 203, 422-441. [CrossRef]

37. Brusco, G.; Burgio, A.; Menniti, D.; Pinnarelli, A.; Sorrentino, N. The economic viability of a feed-in tariff scheme that solely rewards self-consumption to promote the use of integrated photovoltaic battery systems. Appl. Energy 2016, 183, 1075-1085. [CrossRef]

38. Parra, D.; Patel, M.K. Effect of tariffs on the performance and economic benefits of PV-coupled battery systems. Appl. Energy 2016, 164, 175-187. [CrossRef]

39. Subramani, G.; Ramachandaramurthy, V.K.; Padmanaban, S.; Mihet-Popa, L.; Blaabjerg, F.; Guerrero, J.M. Grid-tied photovoltaic and battery storage systems with Malaysian electricity tariff-A review on maximum demand shaving. Energies 2017, 10, 1884. [CrossRef]

40. Nengroo, S.; Kamran, M.; Ali, M.; Kim, D.H.; Kim, M.S.; Hussain, A.; Kim, H. Dual battery storage system: An optimized strategy for the utilization of renewable photovoltaic energy in the United Kingdom. Electronics 2018, 7, 177. [CrossRef] 
41. Singh, R.; Bansal, R.C.; Singh, A.R. Optimization of an isolated photo-voltaic generating unit with battery energy storage system using electric system cascade analysis. Electr. Power Syst. Res. 2018, 164, 188-200. [CrossRef]

42. Koutroulis, E.; Kolokotsa, D.; Potirakis, A.; Kalaitzakis, K. Methodology for optimal sizing of stand-alone photovoltaic/wind-generator systems using genetic algorithms. Sol. Energy 2006, 80, 1072-1088. [CrossRef]

43. Kaldellis, J.K.; Zafirakis, D. Optimum sizing of stand-alone wind-photovoltaic hybrid systems for representative wind and solar potential cases of the Greek territory. J. Wind Eng. Ind. Aerodyn. 2012, 107, 169-178. [CrossRef]

44. Luna-Rubio, R.; Trejo-Perea, M.; Vargas-Vázquez, D.; Ríos-Moreno, G.J. Optimal sizing of renewable hybrids energy systems: A review of methodologies. Sol. Energy 2012, 86, 1077-1088. [CrossRef]

45. Pintér, G.; Baranyai, N.H.; Wiliams, A.; Zsiborács, H. Study of Photovoltaics and LED Energy Efficiency: Case Study in Hungary. Energies 2018, 11, 790. [CrossRef]

46. Available online: http://www.solar.sheffield.ac.uk/ (accessed on 27 October 2015).

47. Nistor, S.; Wu, J.; Sooriyabandara, M.; Ekanayake, J. Capability of smart appliances to provide reserve services. Appl. Energy 2015, 138, 590-597. [CrossRef]

48. Available online: https://www.elexon.co.uk/reference/technical-operations/profiling/ (accessed on 4 April 2018).

(C) 2019 by the authors. Licensee MDPI, Basel, Switzerland. This article is an open access article distributed under the terms and conditions of the Creative Commons Attribution (CC BY) license (http:/ / creativecommons.org/licenses/by/4.0/). 